\title{
Liberals versus conservatives: Personality, child-rearing attitudes, and birth order/sex differences
}

\author{
RUSSELL EISENMAN and HENRY B. SIRGO \\ McNeese State University, Lake Charles, Louisiana
}

\begin{abstract}
Fifty adults who had made monetary contributions to political campaigns were interviewed to determine differences between liberals and conservatives in terms of personality, child-rearing attitudes, and birth order/sex variables. Study 1 found liberals to favor nonrestrictive controls both on self and on children, while conservatives tended to favor the opposite. Women were more likely than men to be liberals, and all first-born females were liberals. In Study 2, the sample as a whole was high in self-esteem and autonomy, and there were no significant differences between liberals and conservatives. Although saying that liberals are Democrats and conservatives are Republicans is accurate to some extent, it misses the fact that many do not identify with either party but consider themselves to be independents.
\end{abstract}

It is usual to think of people's political ideologies as varying along the dimension of liberalism-conservatism. Theoretically, outlooks and behaviors of liberals and conservatives should be different, in both political and other areas (Greenstein, 1975; Lane, 1969). Recent empirical work tends to support this notion (Furnham \& Heaven, 1988; Himmelstein \& McRae, 1988; Jones \& Iacobucci, 1989; Kiecolt \& Nelson, 1988; Ray \& Furnham, 1984; Rinehart \& Perkins, 1989). Concepts of liberal versus conservative are also useful for distinguishing liberals from conservatives in case studies that qualitatively compare the two ideologies (Barrett, 1987). Although it is possible to subscribe to ideologies other than liberalism and conservatism (Fleishman, 1988; Maddox \& Lilie, 1984; Scheb, 1990), the dimension of liberalism-conservatism is the one that is most familiar to people in the United States (Rambo, Myers, \& Scott, 1974).

The present study was concerned with possible differences between liberals and conservatives in three areas: ego control, child-rearing attitudes, and birth-order/sex variables. To ensure that the people studied were ones with some degree of political commitment, our sample was chosen from among persons who had made monetary contributions to political campaigns.

Two measures were used to determine whether a person tended to be a liberal or a conservative. There was reason to suspect that the views of conservatives, due to their desire to keep things pretty much the same, were more restrictive than those of liberals; specifically about such issues as control and child rearing. In contrast, because the liberal political ideology tends to focus on

The order of authorship is alphabetical, indicating equal contribution by the authors. Address reprint requests to either author: Russell Eisenman, Department of Psychology, McNeese State University, Lake Charles, LA 70609-1895, or Henry B. Sirgo, Department of Social Sciences, McNeese State University, Lake Charles, LA 70609-2335. change (Milbrath, 1962), liberals might, by that token, be more oriented toward freedom and have permissive child-rearing attitudes. Birth order and sex differences are often best looked at in combination (Eisenman, in press), and they were examined to see if there were any differences between first borns and later borns and between men and women in terms of their liberal versus conservative ideologies.

\section{STUDY 1}

\section{Method}

Subjects. From the state's public list of political contributors, we randomly selected for interviews $\mathbf{5 0}$ adults who had contributed money to political campaigns in statewide elections. There were 39 males and 11 females. One was black, and the rest were white. On the basis of occupation, income, years of education, and father's income, they tended to be of high socioeconomic status.

Procedure. The interviewees were asked for permission to tape-record the interviews or have the interviewer write down their answers. The device used for tape-recording was a small, unobtrusive, wireless, built-in microphone cassette recorder. The interviews ranged in time from about $22 \mathrm{~min}$ to a maximum of $1 \mathrm{~h} 35 \mathrm{~min}$, with the typical interview lasting about $53 \mathrm{~min}$.

Measures. Two measures were used to scale liberalism-conservatism. The first used eight statements from the Owens's (1967) liberalismconservatism measures, with two minor modifications. First, the word "social" was inserted in one of the statements so that it would read: "The trouble with most of the social programs of the government today is that they cut down on the freedom of the individual." Since both liberals and conservatives may have concerns about various governmental programs, the insertion of the word "social" narrowed the focus of the question. Second, Owens's statement "The federal government has no business sponsoring medical research to find cures for cancer and other serious diseases" was eliminated. While the question may have been a valid discriminator of liberals versus conservatives when Owens first made up his test in 1967, in the 1970s conservatives, including President Nixon, began supporting such research, so the question was deemed no longer appropriate.

The second measure of liberal-conservative ideology was based on seven domestic political issues, such as gun control and government support for mass transit. This measure, which was created for this study, 
had a priori scoring for liberal and conservative viewpoints. People hold more reliable views on domestic than on foreign policy issues (Hamilton, 1968; Nie \& Anderson, 1974), so only domestic issues were used. The liberal or conservative designation of the interviewees was based on their combined score on these two measures.

Ego control was measured by five items taken from Robinson and Shaver's (1973) scales, especially those designed to measure what they called "rigidity" (see Meresko, Rubin, Shontz, \& Morrow, 1954; Rehfisch, 1958). (We use the term "ego control" rather than "rigidity," because it is a more neutral term.) The interviewees' responses were scored on a 9-point agree-disagree scale for liberal versus conservative opinions.

Interviewees' attitudes on child rearing were measured by asking them six open-ended questions, the answers to which could be categorized as reflecting a tendency to allow children to learn on their own ("internal") versus a belief in parental dominance and control ("external").

\section{Results}

Of the 50 adults in the sample, 25 were classified as liberals and 25 as conservatives. Eighteen of the 25 liberals were low and 7 were high in ego control. For the conservatives, the trend was reversed, with 10 of them being low and 15 being high in ego control. This yields a chi-square of $3.98, d f=1, p<.05$, using the correction for continuity in Siegel (1956). Thus, liberals tend to be low and conservatives high in ego control.

Regarding child-rearing attitudes, 22 of the 25 adults classified as liberals expressed a preference for internal child rearing, while 19 of the 25 conservatives preferred external, parentally controlled child rearing. This yields a chi-square of $18.83, d f=1, p<.001$, again using the correction for continuity (Siegel, 1956).

As for sex differences, 10 of the 11 females were liberals; of the 39 males, 24 were conservatives and only 15 were liberals. This finding is significant beyond the .05 level, extrapolating from the tables in Siegel (1956) and converting the findings to two-tailed probability for the Fisher exact test.

The only significant birth-order finding was that all 7 first-born females were liberals $(p<.02$, two-tailed binomial test).

\section{Discussion}

The findings suggest that the dimension of liberal versus conservative is a useful one. There were differences between liberals and conservatives in both ego control and child-rearing attitudes. Regarding ego control, liberals seemed to be much more uninhibited and relaxed, whereas conservatives were more rigid both in terms of permissible behaviors for themselves and in terms of their desire for external and punitive control of their children. Regarding child-rearing attitudes, the conservatives were punitive and controlling, at least to a much greater extent than the liberals. While liberals would generally favor some degree of freedom for their children, conservatives favored guidance, control, and, when deemed necessary, physical punishment. This emphasis on physical punishment of children and parental control is largely absent from the statements of liberals, who favor some parental guidance but also tend to favor letting children have some degree of independence.

With reference to ego control, liberals allow themselves a great range of behavior, while the data on conservatives suggest a preference for a regulated, orderly, and unchanging type of life. Likewise, with regard to the treatment of their children, conservatives favor much more control than do liberals, and are even willing to become physically punitive when children do not obey. Liberals are much more tolerant of their childrens' behavior, and are unlikely to say that they favor physical punishment for infractions. Thus, conservatives favor control for both themselves and their children, while liberals are much more permissive toward both themselves and their children.

Ironically, if they do use physical punishment, conservatives may get the kind of children they do not want. A recent study by Kandel (1990) found that parents who use physical, punitive discipline on their children tend to have children who are aggressive, have control problems, and are disobedient. It may be that punishment and control by the parent serves as a model for the child as to how to behave. Even if the parent is punishing the child for aggression, the parent's own use of punishment of a physical nature shows the child the use of aggression. Thus, the parent uses aggression even while saying, "Don't be aggressive." This is a contradictory message, and the child may pick up more on what the parent does than what the parent says. Likewise, it may be that control, or perhaps excessive control, by the parent does not allow the child to think independently, and thus the child does not learn self-control. That is, the learning of control may require more than the external imposition of control by the parent. Thus, again, both the punitive and the controlling parent would produce a child lacking in control. This speculation is consistent with the view taken by the authors of The Authoritarian Personality (Adorno, Frenkel-Brunswik, Levinson, \& Sanford, 1950) that people with no clear sense of values adopt rigid, authoritarian ones.

Regarding sex differences, the finding that females were more liberal than males is consistent with recent findings regarding the political views of women and their voting preferences in United States presidential elections (Abramson, Aldrich, \& Rohde, 1990; Baxter \& Lansing, 1983; Frankovic, 1982; Ladd, 1985; Nelson, 1985; Pomper et al., 1989; Pomper et al., 1981; Poole \& Zeigler, 1985; Randall, 1982; Sapiro, 1983). A careful reading of these findings suggests that although women tend to be consistently more liberal than men in elections in the United States, they are not always more liberal than they are conservative. For example, more women supported the conservative candidate, Ronald Reagan, over the more liberal candidate, Jimmy Carter, in the 1980 presidential election. However, men supported Reagan over Carter to a greater degree than women did.

The finding that all 7 of our first-born females were liberals is not obviously related to any theory that claims that first-born females would be liberals. In fact, Alfred Adler's view (Ansbacher \& Ansbacher, 1959) was that the first born tends to be a conservative. Clearly, our results are in the opposite direction from what Adler would have predicted. Eisenman (in press) believes that first-born females receive more intensive socialization from their parents than any other birth-order/sex combination. If this is correct, it could lead, in some currently unknown manner, to greater liberalism in first-born females. However, our sample size is small enough to suggest that caution should be exercised in drawing any firm conclusions about the liberalism of first-born females. Clearly, further empirical support is needed for this portion of the study. Overall, the findings suggest that liberals are more open and flexible than conservatives, who are more controlling. This held true regardless of whether our subjects were being interviewed about personal issues (ego control) or about how they believed children should be treated (child-rearing attitudes). Liberals favored a greater degree of freedom; conservatives favored a greater degree of control.

\section{STUDY 2}

In a second study, we used the same sample and looked at possible differences in self-esteem, autonomy, and party identification. Self-esteem was based on up to 10 interview questions that were used to measure self-acceptance, confidence, and so forth; autonomy was measured using 8 interview questions dealing with how free and in control the interviewee felt. While liberals and conservatives did not differ in terms of self-esteem or autonomy, the sample as a whole was high in these areas: 34 of the 50 subjects scored high in self-esteem $\left[\chi^{2}(1)=6.48\right.$, 
$p<.02]$ and 32 of them scored high in autonomy $\left[\chi^{2}(1)\right.$

$=3.92, p<.05]$.

On the one hand, there was a significant tendency for conservatives to be Republicans (10 out of 11) and for liberals to be Democrats (all 18 liberals who chose to identify themselves as Democrats or Republicans called themselves Democrats). This is significant beyond the .01 level by Fisher's exact test. However, 14 conservatives and 6 liberals called themselves independents.

\section{REFERENCES}

Abramson, P. R., Aldrich, J. H., \& Rohde, D. W. (1990). Change and continuity in the 1988 elections. Washington, DC: CQ Press.

Adorno, T. W., Frenkel-Brunswik, E., Levinson, D. J., \& SanFORD, R. N. (1950). The authoritarian personality. New York: Harper.

ANSBACHER, H. L., \& ANSBACHER, R. R. (EDs.) (1959). The individual psychology of Alfred Adler. New York: Basic Books.

BARRETT, S. R. (1987). Is God a racist? The right wing in Canada. New York: University of Toronto Press.

BAXTER, S., \& LANSING, M. (1983). Women and politics: The visible majority (rev. ed.). Ann Arbor: University of Michigan Press.

Eisenman, R. (in press). Birth order and development. In R. Husen \& T. N. Postlethwaite (Eds.), The international encyclopedia of education: Supplementary Volume 2. New York \& Oxford: Pergamon Press.

Fleishman, J. A. (1988). Attitude organization in the general public: Evidence for a bidimensional structure. Social Forces, 67, 159-184.

Frankovic, K. A. (1982). Sex and politics-new alignments, old issues. $P S, 15,439-448$.

Furnham, A., \& Heaven, P. C. (1988). The paradox of socialism: The relationship between social and economic political beliefs. Psychological Reports, 62, 327-332.

Greenstein, F. I. (1975). Personality and politics: Problems of evidence, inference, and conceptualization. New York: Norton.

Hamilton, R. (1968). A research note on mass support for "tough" military initiatives. American Sociological Review, 33, 439-445.

Himmelstein, J. L., \& McRae, J. A. (1988). Social issues and socioeconomic status. Public Opinion Quarterly, 52, 492-512.

JONES, L. E., \& IACOBUCCI, D. (1989). The structure of affect and trait judgments of political figures. Multivariate Behavioral Research, 24, 457-476.

KANDEL, D. B. (1990). Parenting styles, drug use, and children's adjustment in families of young adults. Journal of Marriage \& the Family, 52, 183-196.

KIECOLT, K. J., \& Nelson, H. M. (1988). The structuring of political attitudes among liberal and conservative protestants. Journal for the Scientific Study of Religion, 27, 48-59.
LADD, E. C. (1985). The election of 1984. The Ladd Report No. 1. New York: Norton.

LANe, R. E. (1969). Political thinking and consciousness: The private life of the political mind. Chicago: Markham.

MAdDox, W. S., \& LiLIE, S. A. (1984). Beyond liberal and conservative. Washington, DC: Cato Institute.

Meresko, R., Rubin, M., Shontz, F. C., \& Morrow, W. R. (1954). Rigidity of attitudes regarding personal habits and its ideological correlates. Journal of Abnormal \& Social Psychology, 49, 89-93.

MiLbRATH, L. (1962). Latent origins of liberalism-conservatism and party identification: A research note. Journal of Politics, 24, 679-688.

NeLson, M. (1985). The elections of 1984. Washington, DC: CQ Press.

NIE, N. H., \& ANDERSEN, K. (1974). Mass belief systems revisited: Political change and attitude structure. Journal of Politics, 36, 540-591.

OWENS, W. H., JR. (1967). An operationalized conceptualization of selected ideological variables in the perspective of liberalism and conservatism. Unpublished doctoral dissertation, Florida State University.

Pomper, G. M., Baker, R. K., Burnham, W. D., Farah, B. G., HerSHEY, M. R., Klein, E., \& MCWilliams, W. C. (1989). The election of 1988: Reports and interpretations. Chatham, NJ: Chatham House.

Pomper, G. M., Baker, R. K., Frankovic, K. A., Jacob, C. E., McWillams, W. C., \& Plotkin, H. A. (1981). The election of 1980: Reports and interpretations. Chatham, NJ: Chatham House.

POOLE, K. T., \& ZEIGleR, L. H. (1985). Women, public opinion, and politics: The changing political attitudes of American women. New York: Longman.

Rambo, W. W., Myers, J. D., \& Scott, W. C. (1974). Liberalconservative: Attribution of personal traits to own and opposing ideology. Experimental Study of Politics, 3, 15-22.

RANDAlL, V. (1982). Women and politics. New York: St. Martin's Press.

RAY, J. J., \& Furnham, A. (1984). Authoritarianism, conservatism and racism. Ethnic \& Racial Studies, 7, 406-412.

REHFISCH, J. M. (1958). A scale for personality rigidity. Journal of Consulting Psychology, 22, 10-15.

Rinehart, S. T., \& PERKINS, J. (1989). The intersection of gender politics and religious beliefs. Political Behavior, 11, 33-56.

Robinson, J. P., \& SHAVER, P. R. (1973). Measures of social psychological attitudes (rev. ed.). Ann Arbor, MI: Institute for Social Research.

SAPIRO, V. (1983). The political integration of women: Roles, socialization, and politics. Urbana, IL: University of Illinois Press.

SCHEB, J. M., II (1990). Ideology, issue space and the dimensionality problem: A research note. Southeastern Political Review, 18, 173-184. SIEGEL, S. (1956). Nonparametric statistics: For the behavioral sciences. New York: McGraw-Hill.

(Manuscript received January 8, 1991.) 